\author{
О. Китайка, \\ кандидат юридичних наук, \\ асистент кафедри конституційного права \\ Національного університету «Одеська юридична академія»
}

\title{
СТРУКТУРА КОНСТИТУЦІЙНО-ПРАВОВОГО СТАТУСУ ДИТИНИ В УКРАЇНI
}

Фахівці з права наділяють великого значення дослідженню структури правового статусу дитини. B.I. Абрамов зазначив, що під правовим статусом дитини він розуміє «сукупність іi прав та обов'язків, зафіксованих державою в юридичній формі» [1, с. 14-15]. O.В. Садина, визначаючи основні напрями оптимізації правового статусу неповнолітнього, не обмежується лише згадкою про права, свободи й обов'язки дитини [2, с. 12-13]. Отже, пропозиції цих авторів можна вважати схожими.

Аналізуючи погляди на структуру конституційно-правового статусу дитини, фахівці з права висловлюють різні пропозиціі. О.В. Бутько відмітила: «Кожний конкретний галузевий статус фізичної особи можна визначити як сукупність норм відповідної галузі права ..., що закріплюють його конкретні галузеві права, свободи й обов'язки, а також умови та гарантії їх реалізації» [3, с. 56-57]. На їі думку, у конституційно-правовому статусі особи зосереджено основні елементи (громадянство; принципи правового становища особистості; конституційні права, свободи й обов'язки; гарантіï ї здійснення, а інколи правоздатність і дієздатність фізичної особи), які $€$ провідними для будь-якого галузевого статусу. Але більш точних узагальнень, у т. ч. щодо елементів конституційно-правового статусу дитини, O.В. Бутько в працях не наводить.

H.M. Крестовська визначила конституційно-правовий статус дитини як «систему формально визначених і забезпечених Основним Законом дер- жави прав, обов'язків і відповідальності дитини як повноправного члена украінського громадянського суспільства» [4, с. 33]. Варто зазначити, що фахівці 3 конституційного права, досліджуючи галузевий статус дитини, не зараховують юридичну відповідальність до його елементів, хоча погоджуються 3 тим, що елементами цього статусу $€$ права й обов'язки.

Аналізуючи структуру правового статусу, жоден учений не заперечує щодо включення до нього прав та обов'язків. Але інколи дослідники доповнюють цю конструкцію й іншими елементами.

Зауважмо, що I.В. Волощук із цього приводу зазначає: «Сучасний юридичний концепт виходить із принципу єдності прав та обов'язків дитини» [5, с. 19]. Майже аналогічну думку висловила А.О. Шульц. С.Б. Кордуба стверджує, що «конституційні обов'язки людини та громадянина виступають як об'єктивна необхідність життєдіяльності кожної людини, викладена мовою закону ... Тим самим Конституція нормує межі свободи самої особистості й межі державної влади в їі відносинах із людиною та громадянином» [6, с. 41]. Водночас принцип єдності прав та обов'язків застосовується здебільшого до дорослих, а щодо дітей перевагу має такий спеціальний принцип, як принцип найкращого забезпечення інтересів дитини.

Звернемо увагу на те, що I.В. Волошина зазначає: «У Конституції України прямо не передбачені обов'язки саме дітей, однак, ураховуючи деякі консти- 


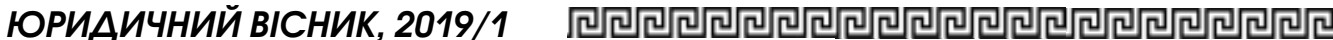

туційні положення та положення інших нормативних актів, можна виокремити систему обов'язків дитини в Україні» [7, с. 125]. Вона пропонує класифікувати конституційні обов'язки дітей в Україні на ті, які безпосередньо стосуються дітей, і ті, які випливають із системи обов'язків людини та громадянина. Однак, виходячи зі змісту їі досліджень, навряд чи обов'язки, які I.В. Волошина аналізує, можна уважати конституційними обов'язками дітей, крім розглянутого обов'язку отримувати повну загальну середню освіту (ст. 53 Конституції України) Також винятком є Закон України «Про освіту», ст. 53 якого передбачає зобов'язання здобувачів «виконувати вимоги освітньої програми ...» [8]. Варто зазначити, що незначна кількість обов'язків дитини в актах конституційного законодавства цілком узгоджується зі змістом відповідних міжнародних стандартів.

Фахівці з конституційного права під час дослідження галузевого статусу дитини приділяють обов'язкам украй незначну увагу. Наприклад, О.М. Кудрявцева та Ю.В. Губаль розглядають виключно конституційні права дитини, а не права в комплексі з обов'язками.

У зв'язку з наведеним не доцільно включати обов'язки дитини до елементів конституційно-правового статусу дитини, адже ті обов'язки, що містяться в Основному Законі України, зазвичай адресовані або всім особам, або громадянам України, але не дітям, а в інших актах конституційного законодавства обов'язків дитини вкрай мало. Шодо тих обов'язків «усіх» або «громадян», про які йдеться в Конституції України, варто зазначити, що під час формулювання цієї тези застосована аналогія, яка полягає в такому: під час аналізу конституційно-правового статусу посадових осіб дослідники не згадують про їхні зобов'язання утримувати неповнолітніх дітей, сплачувати податки тощо, концентруючи увагу лише на тих обов'язках, які випливають із факту обіймання відповідної посади. Відповідно, юридична відпо- відальність включається до елементів конституційно-правового статусу, але здебільшого органів публічної влади чи посадових осіб. Що ж до правового статусу дитини, то юридичну відповідальність доцільно включати як елемент до галузевих статусів дитини, тільки якщо галузь передбачає непоодинокі випадки можливості іï настання до досягнення 18-річного віку.

Важливою $є$ ідея Н.Є Борисової щодо пошуку меж відповідальності дитини. Вона вказує, що межі й усвідомлення відповідальності формуються до повноліття. При цьому правовий статус дитини характеризується не тільки встановленням особливого порядку реалізації ї̈ прав, а й особливим порядком відповідальності, зумовленим обмеженням юридичних обов'язків та особливим обсягом прав дитини. Однак навряд чи авторка має на увазі конституційно-правову відповідальність дитини: у цій сфері відсутній національний нормативний матеріал.

$\mathrm{У}$ юридичній літературі не виникає сумніву щодо необхідності включення прав до структури як правового статусу дитини загалом, так і до конституційно-правового статусу дитини зокрема.

Під час розгляду та грунтовної характеристики кожного суб'єктивного права більшість учених звертає увагу на суб'єкт цього права, а також на його об'єкт і зміст. Отже, правоздатність і дієздатність дитини частково розкривається в процесі дослідження окремих суб'єктивних прав. При цьому правоздатність і дієздатність дитини має певні особливості, які влучно узагальнила Н.Є. Борисова: «По-перше, дитина, як і будь-яка людина, володіє правоздатністю від народження; по-друге, в силу недостатнього вікового фізичного та психічного розвитку дитина не може бути повністю дієздатною, тобто вона не здатна до зрілого, дійового, вольового акту, який передбачає елемент відповідальності. По-третє, оскільки правовий вакуум у контексті забезпечення реалізаціі інтересів практично $€$ неможливим, як наслідок, неповна 
дієздатність має компенсуватися, доповнюватися дієздатністю дорослого та дорослих, у юридичному сенсі їхніх законних представників, що мають повну дієздатність» [9, с. 56-58].

Також правоздатність і дієздатність дитини виявляється в низці міжнародних документів, що мають стосунок до конституційного права. До таких документів належать, зокрема, Конвенція про згоду на взяття шлюбу, шлюбний вік і реєстрацію шлюбу 1962 р.; Kонвенція про мінімальний вік для прийому на роботу № 1381973 р. тощо.

Що ж до громадянських станів дитини, то під час аналізу конкретного суб'єктивного права на них неодмінно звертати увага в межах розгляду суб'єкта цього права. Ця пропозиція міститься в роботах таких авторів, як О.В. Бутько, С.А. Саблук, Л.М. Середа. Звертаючись до нормативної регламентації громадянства дітей в Україні, варто зазначити, що Закон України «Про громадянство України» не містить окремого розділу, присвяченого громадянству дітей. Проблематиці громадянства дітей присвячено лише дві статті цього акта: ст. 11 «Набуття дітьми громадянства України внаслідок усиновлення»; ст. 16 «Необхідність згоди дітей під час набуття громадянства України» [10]. Це свідчить про нормативну прогалину з питання громадянства дітей в Україні.

I.B. Швець справедливо зазначає: «Особливість конституційно-правового статусу дитини полягає в тому, що діти являють собою найбільш складну й уразливу категорію, оскільки, маючи рівні права з іншими, фактично мають набагато менші можливості їх реалізаціï» $[11$, с. 140]. Це свідчить про важливість гарантій конституційних прав дитини. Також про це свідчить і той факт, що міжнародні документи, які містять ювенальні стандарти, включають хоча б декілька гарантій конституційних прав дитини.

У зв'язку з цим наступним елементом конституційно-правового статусу дитини доцільно вважати гарантії кон- ституційних прав дитини. Аналогічної думки дотримуються О.В. Бутько, С.П. Коталейчук, С.А. Саблук, Л.М. Середа, І.В. Швець та інші вчені. Щодо гарантій як елемента конституційно-правового статусу дитини в юридичній літературі не існує єдності не тільки стосовно їх включення до складу цього статусу, а й щодо того, гарантії чого варто вважати елементом конституційно-правового статусу дитини. Як зазначено вище, І.В. Швець веде мову про гарантії реалізації не тільки прав, свобод та обов'язків дитини, а й, імовірно, ще правосуб'єктності, принципів статусу дитини [12, с. 11].

Із цього погляду більш коректним є формулювання Л.М. Середи: «До структури конституційно-правового статусу неповнолітнього входять такі елементи: конституційна правосуб'єктність неповнолітнього; принципи правового статусу неповнолітнього; громадянство неповнолітнього; основні права, свободи й обов'язки; гарантії прав неповнолітнього, а також засоби і способи їх захисту» [13, с. 19].

С.П. Коталейчук зазначає, що «зміст правового статусу особи становлять ii права і свободи, тобто можливості діяти певним чином для задоволення своїх потреб; обов'язки та юридична відповідальність за їх невиконання чи порушення; гарантії забезпечення прав і свобод людини», і уважає, що зміст правового статусу неповнолітнього $€$ аналогічним [14, с. 7]. Отже, він додає до переліку елементів правового статусу дитини ще й гарантії прав.

Вірогідніше, до структури конституційно-правового статусу дитини доцільно включити гарантії конституційних прав дитини. Найбільш поширеною класифікацією гарантій прав є їх поділ на нормативні та організаційні гарантії. Тобто ці гарантії мають посісти чільне місце серед елементів конституційно-правового статусу дитини.

Здебільшого джерелами принципів конституційно-правового статусу дитини в Україні є акти конституційного законодавства (Конституція 


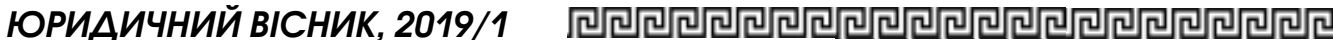

України, закони України), а також відповідні міжнародні документи. Принципи конституційно-правового статусу дитини найбільш грунтовно закріплені в таких міжнародних документах, як Мінімальні стандартні правила $\mathrm{OOH}$ щодо відправлення правосуддя стосовно неповнолітніх (Пекінські правила) 1985 р.; Декларація про соціальні та правові принципи, що стосуються захисту i благополуччя дітей особливо в разі передачі дітей на виховання та їх усиновлення на національному й міжнародному рівнях 1986 р.; Керівні принципи запобігання злочинності серед неповнолітніх (Ер-Ріядські керівні принципи) 1990 р. тощо.

Варто зазначити, що найбільш оптимальним є дослідження принципів конституційно-правового статусу дитини в межах аналізу нормативних гарантій конституційних прав дитини, отже, гарантії конституційних прав дитини будуть безпосередньо співвідноситися з принципами конституційно-правового статусу дитини.

Низка дослідників (О.В. Бутько, С.А. Саблук, Л.М. Середа, І.В. Швець) пропонує включати принципи конституційно-правового статусу дитини до його елементів. Варто зазначити, що багато в чому вони мають рацію. T.A. Яковець справедливо зазначає: «Адекватне розуміння того, що в реальності являє собою конституційно-правовий статус людини, передбачає докладне висвітлення тих основ, завдяки яким формується система прав людини та громадянина й через які забезпечується фактична реалізація цих прав. Зазначені основоположні начала визначаються поняттям «принципи конституційно-правового статусу людини» ... Отже, виходячи з розуміння принципів конституційно-правового статусу людини як визнаних і захищених правом і державою основних засад, на основі яких відбувається реалізація конституційно-правового статусу людини, необхідно визнати, що дослідження системи цих принципів, а також специфіки їх взаємодії в реалізації кон- ституційно-правового статусу людини $є$ невід'ємним складником теоретичних досліджень у галузі конституційного права, теорії прав людини та громадянина» [15, с. 12-13].

Можливість включення або невключення традиційних елементів конституційного статусу особи до елементів їі галузевого статусу підтримана в юридичній літературі. Так, Г.О. Якимов щодо конституційного статусу особи розмірковує: «Основним критерієм включення того чи іншого можливого елемента в структуру конституційного статусу людини $€$ подробиця, розгорнення конституційної регламентації останнього. Низку елементів, які традиційно включають у юридичну конструкцію правового статусу громадянина (або статусу особистості), можна виявити в конституційному статусі людини лише в «згорнутому», стислому вигляді, тому в структуру досліджуваної юридичної конструкції як самостійні елементи вони не входять, ï зміст розкривається в положеннях чинного законодавства (різної галузевої належності)» [16, с. 10-11]. Ця теза $€$ переконливо аргументованою, саме на ній Ірунтуються пропозиції щодо відсутності необхідності включення до складу конституційно-правового статусу дитини таких елементів, як обов'язки та відповідальність дитини.

Отже, можна дійти висновку, що в юридичній літературі сформульовано багато різноманітних пропозицій щодо структури конституційно-правового статусу дитини:

- права/права і свободи (B.I. Абрамов, О.В. Бутько, С.П. Коталейчук, Н.М. Крестовська, С.А. Саблук, О.В. Садина, Л.М. Середа, Ж.Л. Чорна, I.В. Швець);

- обов'язки (B.I. Абрамов, О.В. Бутько, С.П. Коталейчук, Н.М. Крестовська, С.А. Саблук, О.В. Садина, Л.М. Середа, Н.О. Філіпська, Ж.Л. Чорна, I.B. Швець);

- юридична відповідальність (С.П. Коталейчук, Н.М. Крестовська, С.А. Саблук, О.В. Садина, Н.О. Філіпська, Ж.Л. Чорна); 
- гарантії (О.В. Бутько, С.П. Коталейчук, С.А. Саблук, Л.М. Середа, I.В. Швець);

- правоздатність і дієздатність (О.В. Бутько, С.А. Саблук, Л.М. Середа, Н.О. Філіпська, І.В. Швець);

- принципи (О.В. Бутько, С.А. Саблук, Л.М. Середа, І.В. Швець);

- громадянство (О.В. Бутько, С.А. Саблук, Л.М. Середа);

- правові норми (Н.О. Філіпська).

Отже, до структури конституційно-правового статусу дитини варто включити такі елементи, доцільність яких аргументована вище:

- конституційні права дитини;

- гарантії конституційних прав дитини;

- громадянський стан дитини;

- конституційну правосуб'єктність дитини;

- принципи конституційно-правового статусу дитини.

Недоцільність унесення до елементів конституційно-правового статусу дитини iii конституційної відповідальності й конституційних обов'язків зумовлена майже повною відсутністю відповідного нормативного матеріалу та дотриманням державою принципу найкращого забезпечення інтересів дитини.

Ключові слова: конституційно-правовий статус дитини в Україні, права дитини, структура, наукові дослідження.

у статті аналізуються особливості наукових досліджень структури конституційно-правового статусу дитини в Україні з урахуванням сучасних тенденцій $i$ міжнародних стандартів. Аргументована структура конституційно-правового статусу дитини в Україні, елементами якого $є$ громадянський стан дитини, конституиійна правосуб'єктність дитини, принципи конституційно-правового статусу дитини, конституційні права дитини та їх гарантії.

B cmamье анализируются особенности научных исследований структуры конституционно-правового статуса ребенка в Украине c учетом современных тенденций и международных стандартов. Аргументируется структура конституизионно-правового статуса ребенка в Украине, элементами которого являются гражданское состояние ребенка, конституционная правосубъектность ребенка, принципь конституционно-правового статуса ребенка, конституционные права ребенка и их гарантии.

The article defines the features of the child's constitutional status' structure. The author bases the paper on the Ukrainian legislation, taking into account the relevant international standards. The analyzed structure consists of such the elements as follows: child's civic status, child's constitutional personality, principles of the child's constitutional status, child's constitutional rights and their guarantees.

\section{Література}

1. Абрамов В.И. Права ребенка и их защита в России: общетеоретический анализ : Әисс. ... докт. юрид. наук. Саратов, 2007. $455 \mathrm{c}$.

2. Садина О.В. Правовой статус несовершеннолетнего в российском законодательстве: теоретико-правовой анализ : дисс. ... канд. юрид. наук. Саранск, 2009. $205 \mathrm{c}$.

3. Бутько О.В. Правовой статус ребен$\kappa a:$ теоретико-правовой анализ : дисс. ... канд. юрид. наук. Краснодар, 2004. 241 с.

4. Крестовська Н.М. Конституциійно-правовий статус дитини в Україні. Правовий вимір конституційної, адміністративної та фінансової юрисдикції в умовах європейської парадигми України : матеріали Всеукраїнської науково-практичної конференціі (м. Одеса, 17 листопада 2016 р.) Oдеса : Вид-во МГУ, 2016. C. $31-34$.

5. Волощук I.В. Теорія прав дитини: сучасний стан розробки проблеми. Митна справа. 2015. № 2 (2.1). С. 19-24.

6. Кордуба С.Б. Конституциионная обязанность родителей заботиться о детях в Российской Федеращии : дисс. ... канд. юрид. наук. Саратов, 2011. 238 с. 


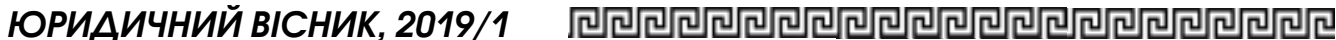

7. Волошина I.В. Конституиійно-правовий статус дитини в Україні : дис. ... канд. юрид. наук. Київ, 2016. 238 c.

8. Про освіту : Закон України від 5 вересня 2017 p. URL: http:// zakon2.rada.gov.ua/laws / show / 1060-12.

9. Борисова H.E. Конституиионные основы правового положения несовершеннолетних в Российской Федерации: проблемь теории и практики : дисс. ... докт. юрид. наук. Москва, 2004. $379 \mathrm{c}$

10. Про громадянство Украӥни : Закон України від 18 січня 2001 р. Відомості Верховної Ради України. 2001. № 13. C. 65 .

11. Швець I.В. Нормативне регулювання конституиійно-правового статусу дитини в Україні. Бюлетень Міністерства юстиції України. 2011. № 10. C. $139-146$
12. Волошина I.B. Конституиійно-правовий статус дитини в Україні: автореф. дис. ... канд. юрид. наук. Київ, 2016. 20 с.

13. Середа Л.М. Обеспечение прав несовершеннолетних органами местного самоуправления : дисс. ... канд. юрид. наук. Краснодар, 2006. $185 \mathrm{c}$.

14. Коталейчук С.П. Теоретико-правові проблеми правового статусу неповнолітніх в Україні та забезпечення його реалізациї як один із основних напрямків діяльності міліції : автореф. дис. ... канд. юрид. наук. Kuїв, 2004. 20 c.

15. Франиуз-Яковець Т.А. Забезпечення конституиійно-правового статусу людини $i$ громадянина в Україні : автореф. дис. ... канд. юрид. наук. Одеса, 2007. 20 c.

16. Якимов Г.А. Конституиионный статус человека в Российской Федерациии: вопросы теории и практики : дисс. ... канд. юрид. наук. Екатеринбург, 2009. 206 с. 